TITLE:

\title{
Gene expression profiling in human esophageal cancers using cDNA microarray(Abstract_要旨)
}

$\operatorname{AUTHOR}(S)$ :

Kan, Takatsugu

CITATION:

Kan, Takatsugu. Gene expression profiling in human esophageal cancers using cDNA microarray. 京都大学, 2003, 博士(医学)

ISSUE DATE:

2003-03-24

URL:

http://hdl.handle.net/2433/148738

RIGHT: 


$\begin{array}{lllll}\text { 氏 } & \text { 名 } & \text { 加 } & \text { 䖯 } & \text { 嗣 } \\ \text { 学位(専攻分野) } & \text { 博 } & \text { 士 (医 学) } \\ \text { 学位記 番号 } & \text { 医 } & \text { 博 } & \text { 第 } 2615 \text { 号 }\end{array}$

学位授与の日付平成 15 年 3 月 24 日

学位授与の要件学 位 規 則第 4 条第 1 項 該 当

研究科・専攻医学研究科分子医学系専攻

学位論文題目 Gene expression profiling in human esophageal cancers using cDNA microarray

（cDNA マイクロアレイを用いた食道癌における遺伝子発現プロファイル）

論文調查委員教授小川修教授藤田潤教授今村正之

\section{論文 内容 の 要旨}

(緒言)

食道癌患者の予後に様々な遺伝子の発現が関与すると考えられている。申請者は，食道癌患者の治療法選択，予後判定， 分子生物学的分類などを目的に，食道癌の遺伝子発現を cDNA マイクロアレイで解析した。

（材料と方法）

食道扁平上皮癌細胞株（SCCs）（KYSE seies）10株，食道腺癌細胞株（ACs）（SKGT-4，TE7，KYAE，OE-33） 4 株, 食道癌切除組織（CTs） 8 例を用いた。癌細胞株（CCLs）には正常食道上皮細胞株を対象とし，癌組織には正常食道 組織を対象とした。DNA チップはHuman Cancer Chip ver. 2.0（TaKaRa）を用いた。抽出したmRNA 1 $\mu$ gをそれぞれ Cy3，Cy5 で蛍光標識して cDNA を作製し，プレパラート上でHybidization した。Scanner は Affymetix Array Scanner 428, 解析は ImaGene 3.0 (BioDiscovery), Cluster, Tree View (Stanford 大学)を使用した。

(結果)

(1) クラスタリング解析により， SCCs と ACs は遺伝子発現プロファイルが明らかに異なっていた。特に OE- 33 と KYAE は遺伝子発現において共通するプロファイルが多くみられた。一方, SKGT-4 と TE7 は KYSE seies の近傍にク ラスタリングされ，食道腺癌でありながら食道扁平上皮癌と共通の遺伝子発現を多く持つことが明らかとなった。

(2) CTs では全ての遺伝子発現プロファイルを解析に用いると，クラスタリングによって予後分類はできなかった。し かし，統計学的に発現差のある遺伝子を 23 個抽出し，再度クラスタリングを行ったところ，予後分類が可能であった。さら に予後の判明している新たな 1 例を加えたところ，予測されたカテゴリーに分類された。抽出された 23 個の遺伝子の内，細 胞周期関連遺伝子（PCNA，cdc25c，cdk10）と増殖因子関連遺伝子（HGF receptor，FGF2）が予後不良群で高発現を示 した。

（3） SCCs と ACsに扔いて発現に差のある遺伝子と，CCLs とCTsに扔いて発現に差のある遺伝子があった。特に，食 道癌組織は食道癌細胞株に比較して, MMPs や plasminogen activator どの細胞外マトリックス分解酵素関連遺伝子の発 現が著明に充進していた。

(4) PPAR- $\gamma$ の発現に执いて，マイクロアレイで得られた遺伝子発現と LightCycler による半定量 PCRに相関があった。 (結論)

（1） SCCs と ACs， CCLs と CTs は，増殖因子，細胞周期，接着因子，細胞骨格因子，アポトーシス関連因子において 異なる遺伝子発現プロファイルであることが明らかになった。

（2）食道癌の遺伝子発現プロファイルを用いた clusteringにより予後解析の可能性が示唆された。マイクロアレイによる 遺伝子発現解析は治療法選択，予後判定，分子生物学的分類などに有用であると考えられる。 


\section{論文 審査の 結 果 $の$ 要 旨}

食道癌の発生と進展に関与する様々な遺伝子が研究されている。申請者は食道癌における分子生物学的分類や予後判定を 目的として, 食道扁平上皮癌細胞株 (SCCs) 10株, 食道腺癌細胞株 (ACs) 4 株, 食道癌切除組織 8 例についてマイクロ アレイ（Human cancer chip ver. 2.0, TaKaRa，約420遺伝子）による遺伝子発現プロファイル解析を行った。（結果）(1) $\mathrm{SCCs}$ は類似性の高い遺伝子発現プロファイルを示し，ACs は SCCs と比較的類似したプロファイルを示すものと著明に異 なるものとがあった。(2)食道癌切除組織において統計学的に有意に発現に差のある遺伝子23個を用いたクラスタリングによ り予後分類が可能で，予後の判明している新たな 1 例も予測されたカテゴリーに分類された。細胞周期関連遺伝子 (PCNA，CDC25C，CDK10）と增殖因子関連遺伝子（HGFR，FGF 2，ILGF-1R）が予後不良群において高発現してい た。(3)食道癌切除組織は食道癌細胞株に比較して, 細胞外基質分解酵素関連因子（MMPs, PA）や組胞外基質 (collagens）の発現が妄進していた。（結論）マイクロアレイによる遺伝子発現解析は食道癌における分子生物学的分類に 有用であり，予後判定にも応用が期待された。

以上の研究は，食道癌の遺伝子発現の解明に貢献し，予後判定，分子生物学的分類などに寄与するところが多い。 したがって，本論文は博士 (医学) の学位論文として価値あるものと認める。

なお，本学位授与申請者は，平成15年 2 月 26 日実施の論文内容とそれに関連した試問を受け，合格と認められたものであ る。 